\title{
Victimized State and Visionary Leader? Questioning China's Approach to Human Security in Africa
}

\author{
Yih-Jye Hwang ${ }^{1}$ (D) - Lindsay Black ${ }^{2}$
}

Received: 5 September 2019 / Accepted: 15 January 2020 / Published online: 29 January 2020

(C) The Author(s) 2020

\begin{abstract}
Over the past decades, numerous critiques have emerged of China's policy towards Africa. These critiques perceive China as a mercantilist or neocolonial power seeking to dominate the African continent through land grabs, exploitative trade deals, and resource extraction. These critiques do however not consider how the Chinese government has attempted to justify its aid policy towards Africa in ways that claim to secure human beings. Though the Chinese government has not officially adopted the concept of human security, it has engaged with the concept and developed its own interpretation of how human beings should be secured. This interpretation is based on the depiction of China as a state victimized through imperialism that has emerged in the twenty-first century as a global power with visionary ideas. Accordingly, Chinese policymakers believe they can offer an alternative model to Western interventions, imposition of neoliberal economic doctrine, and emphasis on democratization and human rights. In Africa, though China's vision has generated benefits for some, it has also victimized others. China needs to critically reflect on and adapt its developmental vision if it truly intends to help human beings overcome the myriad challenges they face in their daily lives.
\end{abstract}

Keywords China $\cdot$ Africa $\cdot$ Human security $\cdot$ Identity $\cdot$ Development

\section{Introduction}

Over the past 15 years, numerous critiques have emerged of China's policy towards Africa. Governments, media, think tanks, and scholars have criticized China's foreign

Yih-Jye Hwang

y.c.huang@luc.leidenuniv.nl

Lindsay Black

1.black@hum.leidenuniv.nl

1 Leiden University College, Leiden University, Leiden, Netherlands

2 Institute of Area Studies, Leiden University, Leiden, Netherlands 
policy towards Africa as being self-interested, mercantilist, and failing to address human rights concerns and the continent's political problems. For Naim [45], China is a specialist in "rogue aid," namely, opaque and self-interested assistance that undermines human security and development. Chinese assistance is often labeled a form of neocolonialism focused on promoting Chinese business interests in and acquiring natural resources from Africa [68]. The deals Chinese actors sign with African states are unequal, leaving African states with inferior infrastructure that they are reliant on Chinese firms to maintain. Taylor [66] argues that the Chinese government "effectively legitimizes human rights abuses and undemocratic practices under the guise of state sovereignty and "non-interference" in its search for African oil (see also [63]). China's activities enable rogue states to survive, threatening the stability of the international system, according to Zweig and Bi [83]. Such views have been echoed by United States (U.S.) officials, including Johnnie Carson, the former U.S. assistant secretary of state for Africa, who labeled China "a pernicious economic competitor with no morals" in a commentary published on Wikileaks [56]. More recently, the former U.S. National Security Advisor John Bolton [8] pointed to China's economic expansion and "predatory practices" as a threat to the U.S. as his speech at the Heritage Foundation. According to Bolton

Chins uses bribes, opaque agreements, and the strategic use of debt to hold states in Africa captive to Beijing's wishes and demands. Its investment ventures are riddled with corruption, and do not meet the same environmental or ethical standards as U.S. developmental programs. Such predatory actions are subcomponents of broader Chinese strategic initiatives ... a plan to develop a series of trade routes leading to and from China with the ultimate goal of advancing Chinese global dominance.

The Western media also perpetuates a view that China exploits a weak continent in comparison to the benevolence of the West's engagement with Africa [38].

There have been numerous responses to these charges that have sought to provide more nuance in terms of China's relations with Africa. First, commentators note that China's behavior is not so different from other (Western) states' foreign policies towards Africa [56]. Second, critics of China's foreign policy towards Africa fail to consider the multitude of Chinese actors operating on the continent and the difficulty for Beijing in maintaining control over the behavior of these diverse actors [69]. Third, African views of Chinese foreign policy on their continent are more positive than the critics acknowledge, though arguably these responses are not as positive as Beijing would like [59]. Fourth, the paternalistic Western model of engaging Africa has hardly been successful, whereas China's business-orientated approach does at least build infrastructure, and provide jobs and educational opportunities for Africans [57].

What these responses have not done is to consider how the critiques of China's engagement with Africa rely on a specific Western understanding of human security based on armed interventions, the imposition of neoliberal economic doctrine, and an emphasis on democratization and human rights. Though the Chinese government has not officially adopted the concept of human security, it has engaged with the concept and developed its own interpretation of how human beings should be secured $[12,74]$. 
The aim of this paper is to understand how Chinese officials have based their interpretation of human security on the depiction of China as a state victimized through imperialism that has emerged in the twenty-first century as a global power with visionary ideas. The narrative of China as a visionary draws primarily on a traditional Sino-centric understanding of order and China's developmental experience. Chinese officials and scholars have therefore framed the concept of human security in terms of "freedom from want" to various degrees, and adopted a developmentalist approach to human security. These Chinese officials and scholars have tended to argue that the essence of security should not be exclusively militarily and politically focused. This interpretation of human security has then been deployed to justify and sustain China's foreign policy towards Africa in the public domain. At the same time, the discursive foundations of China's foreign policy towards Africa serve to undermine human security by preventing a critical appraisal of Sino-African relations.

One of the main contributions of this paper is therefore to answer the call to seriously engage with how human security is understood differently throughout the world [51, 61]. As there are multiple dimensions of security, so it is essential to critically engage with how security issues are defined and approached from specific localities and agents rather than imposing a universal approach as some Western advocates of human security have sought to do in terms of promoting an interventionist interpretation of the concept. This is vital considering calls by Western leaders to end interventionist approaches that seek to "remake the world in [their] own image" as Western attempts at global leadership falter [6]. Can China provide global leadership that secures human beings in an age in which Western states turn increasingly inward?

This paper begins by examining how China's engagement with human security draws on its self-identification in international society as both a victimized state and visionary leader. Next, the argument explains how the Chinese government has mobilized its interpretation of human security to justify its policy towards Africa. In the subsequent section, the paper provides a critique of how the rhetoric of the Chinese government has in turn sought to hide the victims of its policy towards Africa. By way of conclusion, the article argues that it is important to understand the discursive foundations of Chinese approaches to human security and how they inform China's policy towards Africa. While acknowledging that China's foreign policy towards Africa has been beneficial for some, it has also created new victims. Chinese officials and scholars need to critically reflect on and adapt China's developmental vision if it truly intends to help human beings overcome the myriad challenges they face in their daily lives.

\section{Understanding China's Engagement with Human Security}

As a rising power, China has had to articulate a global vision that answers the question of how human beings ought to be secured. The Chinese government therefore engaged with the human security paradigm, which emerged in 1993 with the publication of a United Nations Development Program (UNDP) reports to challenge the political realist-derived orthodoxy that employed a military-focused and state-centric approach to security [71]. Human security thereby shifted the primary security referent from the state to the human being by focusing on "freedom from want," comprising 
development issues such as the provision of health care, education, and employment; and on "freedom from fear," comprising protection issues such as denoting liberation from political oppression and physical harm. Proponents of human security welcomed its all-encompassing scope by interrelating urgent and crucial issues that human beings face on a daily-basis, ranging from poverty, climate change, environmental degradation, pandemic control, and food security to social and political rights. Such issues are often analyzed separately across a variety of fields of study rather than as an interconnected group [74].

Despite its focus on threats to human life and expansion of the concept of security, the human security paradigm received a great deal of criticism. Critics charged that the concept was vague [32], state-centric [46], and served neoliberal agendas [15], constituting no more than a form of colonial governance in a postcolonial world that encourages resilience in the face of perennial threats [51,60]. Scholars, such as Edward Newman [46], sought to address these critiques by developing a Critical Human Security Studies (CHSS) agenda. Newman's embrace of Western-centric frameworks that seek to liberate foreign others, however, raised a further critique that human security implants Western approaches that fail to engage with the subaltern voice or consider how human security is conceived of in different parts of the world. As Pasha [51] and Shani [60] maintain, a critical understanding of human security has to focus on how individuals articulate security concerns in their everyday lives and from their own specific cultural and religious perspectives.

These critiques can all be applied to Western, especially European, states which have linked their aid and human security policies to the idea of human rights and good governance. In terms of freedom from fear, Western states have promoted nontraditional norms of intervention - or what John Kabia [29] called "coercive humanitarian intervention" - in the post-Cold War environment to counter what they perceived to be emerging security threats such as genocide, ethnic cleansing, failed states, massacres, or crimes against humanity in international affairs. The introduction of these norms resulted in more intrusive armed responses aimed at state-building, humanitarian intervention, and peace enforcement, particularly on the African continent. In terms of freedom from want, following the publication of the World Bank report in 1981 entitled "Accelerated Development in Sub-Saharan Africa: An Agenda for Action" by Elliot Berg [7], Western developed countries frequently imposed "structural adjustment" programs comprising austerity and liberalization measures on recipient countries in return for access to various forms of aid, investment, and loans. In this vein, the Western countries, especially the European Union (EU), which identifies itself as a normative power [37], regards itself as the "protector" or "ethical teacher" of developing countries (in particular the African states). This constitutes a paternalistic relationship, which is arguably, rooted in Europe's colonial history.

Rather than accept these Western definitions of human security, China has understood the concept based on its constructed self-identity as a state victimized through imperialism that has emerged in the twenty-first century as a global power with visionary ideas. In contrast to Western liberal states, China frames the concept of human security differently in accordance with a traditional Sino-centric view of order that perceives China's relations with foreign states as benevolent and based on the concept of non-interference. In addition, its constructed self-identity as a developing state has resulted in its officials and scholars framing the concept of human security in 
terms of "freedom from want" and adopting a developmentalist approach to human security. The fusion of the victim and visionary narratives is both pragmatic and idealistic and can be seen to offer an alternative model to the West, by rivaling the central tenets of Western approaches to human security that emphasize intervention, neoliberal economic doctrine, democratization, and human rights. The following subsections expand on how historical legacies, traditional worldviews, and specific developmental contexts have informed China's approach to human security.

\section{China's Victim Narrative and Human Security}

China's victim narrative derives from what has been dubbed its "century of humiliation," a period of foreign domination spanning from the mid-nineteenth century Opium Wars until the Chinese Communist Party victory in 1949. This was a period of national weakness during which imperial powers intervened in China's domestic affairs to extract concessions spanning from trade to property rights. The contemporary narrative argues that intervention came not only at the expense of the Chinese state, debilitating its development and undermining its prestige, but also undercut the welfare of the Chinese people themselves. The emphasis on securing China's borders from external intervention therefore became central to China's identity narrative and sovereignty became the core aspect of Chinese understandings of both national and human security. To the Chinese government, if a country cannot protect its national sovereignty, then there can be no human security for its people [41].

As Chinese scholars and foreign policymakers began engaging with the concept of human security, so they also drew comparisons between Western interventions in the post-Cold War era with China's own "century of humiliation," seeking to distinguish China's approach to human security from that of former imperial powers. From the outset, Chinese policymakers were wary of Western interpretations of human security that equated the concept with human rights issues and humanitarian intervention [12]. ${ }^{1}$ Instead, they stressed that the inherent diversity of world politics must be respected. As Xi Jinping noted, "[countries] differ in size, wealth and strength. They vary in historical and cultural traditions as well as social systems, and have different security interests and aspirations" [75]. China has long been promoting what it calls "a multipolar world" and advocating "democracy" in international relations. Xi, in his remarks at the Fourth Summit of the Conference on Interaction and Confidence Building Measures in Asia, notes that security must be inclusive. He says

We should abide by the basic norms governing international relations such as respecting sovereignty, independence and territorial integrity and noninterference in internal affairs, respect the social systems and development paths chosen by countries on their own, and fully respect and accommodate the legitimate security concerns of all parties. [75]

In this regard, national security and human security are interwoven and complimentary to each other.

\footnotetext{
${ }^{1}$ For a comprehensive review of China's engagement with the concept of human security, see [12].
} 
At the same time, Xi's statement is a call to understand security from specific cultural and historical perspectives and is therefore a clear critique of the mainstream, Western understanding of the universality of human security. Essentially, China has battled with what it perceives as a Western notion of human security and Responsibility to Protect (R2P) designed to facilitate interference in other countries' domestic affairs, especially in the "third world." China associates such invasive approaches to its own experiences of foreign imperialist interventions during a "century of humiliation." Thus, China has been critical of the notion of "intervention." It has assiduously promoted "sovereignty" as a core value in its conception of human security. ${ }^{2}$

The focus on sovereignty in China's approach to security is apparent in Xi's comments at the first meeting of the newly founded National Security Commission of the Communist Party on 15 April 2014. Xi asserted that China should "follow the principle of people first, and maintain that everything done for national security is for the sake of the people, by relying on the people, and through gaining the support from the people" [16], making this a guiding principle in China's security thinking. Elaborating on this point to make a clear connection with many of the concerns that encompass human security, Xi stated [16],

China should pay close attention to both traditional and non-traditional security issues, and build a national security system that integrates such elements as political, homeland, military, economic, cultural, social, science and technology, information, ecological, resource, and nuclear security.

The Chinese leadership's sensitivity towards Western understandings of human security resulted in them seldom employing the concept in their official discourse; one notable exception being former President $\mathrm{Hu}$ Jintao speech at the APEC Summit in Chile in 2004, where he alluded to natural disasters like earthquakes, typhoons, droughts, and tsunamis in terms of human security. $\mathrm{Hu}$ also promised that China would actively support and participate in APEC's disaster prevention, alleviation and post-disaster reconstruction efforts, so as to effectively protect the security of human life and property in the region [42]. Nevertheless, China's wariness regarding human security, the concept was translated in a variety of terms, such as "comprehensive security," “new security," and “people's security” (人民安全), and became embedded in Chinese domestic and international security policies, as Xi's comments above highlight.

Notwithstanding the differing uses of the above terms and some inherent contradictions, in the last decade, Chinese conceptualizations of security have broadened to incorporate the concerns of the UNDP 1994 definition of human security. The country has increasingly moved towards a more comprehensive conception of security, including human security that is grounded in a victim narrative.

\footnotetext{
2 Though it is beyond the scope of this article, China's conception of sovereignty is contested by people in Tibet, Xinjiang, and Hong Kong who seek a degree of political independence. The Chinese government does not tolerate such challenges, arguably undermining the human security of Tibetans, Uighurs, and citizens of Hong Kong.
} 


\section{Sino-centric Order and Human Security}

Rather than concentrating on foreign political intervention, the Chinese government stresses win-win relations based on non-intervention and respect. This line of thought is derived from the Chinese notion of legitimacy, which is originally grounded in the premodern political idea, the mandate of heaven. The mandate of heaven ties in with the propriety of the ruler, or the ruler's virtue (德). It is important to note that the ideal of a ruler's virtue was not merely an ideological construct, but required actual material benefits for the populace [18]. The way for rulers to secure the "hearts of the people" (民心) was not only to possess "benevolence" (仁), but also to perform their duties well, which is interpreted as assuring people's safety and well-being. As long as the leadership is able to demonstrate its benevolence to its citizens by assuring their welfare, the citizens are believed to be willing to support their rulers rather than rise up against them. The legitimacy of rulers was thus to a large extent performance-based. The Chinese government has actively facilitated the work of scholars including Qin Yaqing [55], Yan Xuetong [78], and Zhao Tingyang [81] who have embraced traditional Confucian ideas to justify CCP rule and China's domestic and foreign policies, including notions such as China's "peaceful development" and "harmonious world" $[19,33]$.

It is important to note that according to the rhetoric of a heavenly mandate, the "benevolence" performed by the rulers (i.e., emperors) not only refers to the imperial subjects (i.e., the Chinese people) but also to "foreigners," (i.e., tributary states and people living beyond the circle of tributary states). The imperial Chinese Sino-centric system was portrayed as a model of benevolent governance reflecting core Confucian values both internally and externally [49]. It signified an "attraction" of the outer fringes of Chinese civilization to become part of the Sino-centric system. Chinese emperors were considered to be Sons of Heaven, governing not just China but "all under heaven," or Tianxia.

Recent works on China's international relations [17, 30, 80, 81] maintain that this Tianxia mentality has influenced Chinese foreign policy. The contemporary narrative of Tianxia in state and Sino-centric terms also shapes how China's approach to human security is defined in terms of an acceptance of top-down governance guaranteeing economic development for the well-being of the people. As China continues its economic successes, the role of the Chinese traditional worldview is likely to continue to increase [82]. Policymakers are encouraged to incorporate the rhetoric of intellectual work that supports the application of Chinese traditions in foreign policy. References to China's Confucian heritage in its foreign policy might not seem realistic and have been critiqued for comprising a new hegemony [14], but they do sketch a global vision that the Chinese government strives for.

\section{China's Developmental Experience and Human Security}

The Chinese government maintains that human security should focus on economic development, arguing that if the government fails to ensure the well-being of its people, then the people will revolt against the government. Using China itself as an example, the Chinese government frequently equates economic development with human security when noting the achievement of lifting two-thirds of its population out of poverty 
since its reform and opening-up policy began in 1978 [26, 53]. The most recent poverty alleviation campaign under Xi's administration aims to eliminate all rural poverty by 2020 [67]. In addition to eliminating poverty, it says that China's economic policies have also rapidly improved the quality of life for the majority of its people, building a Chinese society of relative prosperity in all respects. In the opinion of Chinese officials, two historic leaps have been realized: first, from poverty to citizens having adequate food and clothing, and second, from adequate food and clothing to the people becoming relatively prosperous [24]. According to the Chinese government, the next step is to transform China into a global manufacturing leader under the strategic plan called "Made in China 2025" [65].

According to this rhetoric, the "right to development" is particularly highlighted. The notion of "development" seems to be an all-inclusive key to the well-being of the people, or human security. For the Chinese government, the right to development is a fundamental human right and of primary importance. Xi has promoted the notion of sustainable security on various occasions. He elaborates on this concept as follows

[We] need to focus on both development and security so that security would be durable. As a Chinese saying goes, for a tree to grow tall, a strong and solid root is required; for a river to reach far, an unimpeded source is necessary. Development is the foundation of security, and security the precondition for development. The tree of peace does not grow on barren land while the fruit of development is not produced amidst flames of war ... [Development] means the greatest security and the master key to regional security issues. [75]

In this vein, development is not only the key to securing freedom from want but also a way to attain freedom from fear. The best remedy for conflict and instability is sustained economic development. For example, Hu Jintao's New Security Concept stressed that "it would not be possible to attain peace without achieving socio-economic development and the pursuit of economic development in conflict areas should be an integral part of any peacekeeping effort" [50]. To Beijing, armed conflicts are merely a "symptom," whereas socio-economic development should be regarded as the root cause. Moreover, in Beijing's rhetoric, only if one is independent economically, can one be independent politically. Protecting one's sovereignty therefore achieves human security for one's people. Thus, for the Chinese government, the best strategy for promoting human security is to focus on such issues as reducing poverty through development. While such strategies are not overtly directed to improving freedom from fear issues such as civil rights, the Chinese government asserts that the people do gain better access to health care, education, and resources. According to the Chinese government, by accessing such resources, communities are better able to confront the freedom from fear issues they face.

The equation of freedom from want preceding and resolving freedom from fear issues is apparent in all aspects of China's engagement with the notion of human security. For example, Chinese officials claim that improving the region's economy through the Asian Infrastructure and Investment Bank (AIIB) Initiative could weaken the root causes of terrorism and help stabilize Central Asia and the Middle East. As Xi notes, "we need to advance the process of common development and regional 
integration, foster sound interactions and synchronized progress of regional economic cooperation and security cooperation, and promote sustainable security through sustainable development" [75]. This hybrid conception contrasts with Western understandings of human security that differentiate "freedom from want" from "freedom from fear," with a focus on the latter, i.e., individual political rights such as freedom of speech, assembly, and religion.

China's interpretation of human security to emphasize freedom from want issues is also due to its identification as a Third World developing country that has just recently transformed itself from a former aid recipient into an aid donor. Brautigam [9-11], in her studies of China's role in Africa, discussed China's domestic history extensively as she believes that this is pivotal to understanding the rationale behind China's strategic goals as well as the implications these actions might have on the development of African countries. To Brautigam, the role China plays in being a development aid donor in Africa originates in the experiences China had itself with regard to developing its own nation and the aid it received from Japan. Indeed, China can be said to have adapted its strategies from the aid it itself has received from Japan [62]. ${ }^{3}$ As Brautigam [9 p. 60] states,

China's aid - like Japan's - is influenced by a regional pattern: the developmental state. Over time, foreign aid has become one tool in a range of economic instruments adeptly managed by China's state leaders to boost China's exports and its own development. Aid and other benefits are used not only to support the development of recipients, but to foster trade, help build competitive Chinese multinational corporations, and encourage the upgrading of China's own domestic firms.

China's stance on providing development aid was significantly influenced by its constructed self-identity as both a "developing" and "developmental" state-with centrally planned interventions designed to boost production, infrastructure, and trade.

China has tried to sell its own experiences and the development model, perceiving China's achievements as a blueprint for the development of the "Third World," especially for countries in Africa. Providing such a blueprint is something that Chinese officials have argued the West has not managed to achieve with their aid and human security policies. In short, the Chinese aid and economic cooperation programs, interpreted as human security, have been heavily shaped by its own experience of development. China's interpretation of human security can be observed in the country's engagement with Africa and how its understanding of human security has been mobilized in response to critics of China's Africa policy.

\section{China's Engagement with Human Security in Africa}

Contrary to the West, China's discourse of human security has stressed its win-win approach to aiding African countries and promoted the idea that there exists a feeling of

\footnotetext{
${ }^{3}$ The real difference between China and Japan's aid policies is that Japan, as a DAC member, has had to implement policies relating to human rights, rule of law, and good governance.
} 
similarity and even solidarity between China as a donor and the recipient nations. With regard to freedom from want issue, China has not required that political or ethical conditions be attached to their development aid and business contracts [15, 31]. While Western countries often find it hard to work cooperatively with local African partners because of certain ethical and political considerations, China asserts that it follows a policy of non-interference that emphasizes the principles of equality of state sovereignty. The origin of China's non-intervention aid model can be found in former premier Zhou Enlai's articulation of the Eight Principles for Economic Aid and Technical Assistance to Other Countries in 1964, which stated that "the Chinese government strictly respects the sovereignty of recipient countries, and never attaches any conditions or asks for any privileges" [40]. This principle of non-political conditionality remains in China's contemporary foreign aid rhetoric. While this may be seen as a flaw of China's human security policy by some of its critics (e.g. [4]), the Chinese government asserts that it respects the customs and regulations of African nations and does not impose its own ideals on them.

For instance, during his tour of Africa in 2006, the then Chinese Premier Wen Jiabao said "China was the victim of colonial aggression. The Chinese nation knows too well the suffering caused by colonial rule and the need to fight colonialism" [52]. It is this "shared" experience as victim of colonialism that is used to justify China's nonintervention aid model in Africa. By doing so, China has been able to rhetorically position itself as a collaborative partner for Africa emphasizing win-win relations and striving for a more harmonious world in which there is no place for (neo) colonial or (neo) imperial aggression. The fact that China does not have a record of a violent historical presence in Africa characterized by slavery, imperialism, or intervening in the domestic affairs of African states has been an advantage in promoting its case. Chinese officials continue to base their rhetoric on "Chinese exceptionalism" as they maintain that China sees Sino-African relations as a reciprocal relationship based on mutual benefit rather than on colonial intentions [2], echoing the "China as victim" and "benevolent leader" discourses outlined earlier in the paper.

China's rhetoric of "mutual benefit" is designed to justify a business-oriented approach to human security, in which China focuses on commercial and economic transactions that are aimed at facilitating both further economic growth in China and individual African countries [5]. Investment, rather than grant aid, has therefore proven key to China's development policy. China connects development aid with corporate business through new and innovative methods.

As Dreher et al. [21] note, China's overseas development aid is broadly defined in line with the one suggested by the OECD Development Assistance Committee. Yet, it is more flexible in practice, combined with grants, trade, investment, and loans. According to OECD definition [48], international aid to developing countries is divided into two categories: Official Development Assistance (ODA) and Other Official Flow (OOF). The latter is defined as official sector transaction that does not meet the former's criteria-i.e., having a grant element of less than $25 \%$. China's aid to African countries includes both ODA and OOF, but in terms of proportion, its OOF far outweighs its ODA. According to Dreher, et al. [20], only $23 \%$ of China's foreign aid funding is considered as ODA while other $77 \%$ is OOF. The U.S. is just the opposite, in which 93\% of its foreign aid expenditure is ODA. As China's White Paper on Foreign Aid [64] stresses, China aims to help recipient countries improve their independent 
development capabilities, being able to use their own resources and gradually becoming self-reliant. China regards its foreign aid as mutual assistance among developing countries, or what is called the "South-South Cooperation." In this process, China and the recipient countries can simultaneously benefit each other. By establishing mutually beneficial partnerships, the Chinese government maintains that it can pursue the national interests of both itself and the African states at once.

China's mutually beneficial model is justified by the rhetoric of "poor helping poor." As noted in the previous section, China's idea and practice of human security is largely shaped by its own developmental experience. After China's Reform and Opening Up, China's achievements in eliminating domestic poverty without overly relying on foreign aid were well acknowledged, and that experience strengthened its confidence in assisting other developing countries. Under Mao Zedong, China's approach to alleviating domestic poverty mainly consisted of allocating state's funds and subsidies directly to poor areas in the country. However, after the Reform and Opening Up, state funds became more restricted due to the introduction of a market economy to China. As a result, China gradually moved to a development-type of poverty alleviation, wherein the government introduced industrial and commercial investment in poor areas, aiming to develop natural or human resources so as to increase productivity. Since the 1980s, this approach to poverty alleviation has proved to be successful. Chinese experiences of its domestic poverty alleviation in turn shaped Beijing's view on international aid. From the 1980s, Beijing began to amend its international aid strategies and incorporate the concept of development-type poverty alleviation - a combination of investment with aid [36]. As Deng Xiaoping famously noted, China (under Mao) had been "too enthusiastic thereby encouraging Africans to depend on us (China)" [79] leading to a misuse of aid funds. After 1995, foreign aid was officially merged with investment and loans [54], to become "typical development aid" [35].

China's win-win approach to adding African countries is not simply self-serving instrumental rhetoric, but is based on an official understanding of how China's approach to alleviating poverty at home could be a model to export abroad through its aid policy. This also explains why China's approach to international development is different from developed countries, especially those in the West. Though China's economy has boomed, Chinese White Papers on Foreign Aid continue to identify China as a developing country [64], depicting China's aid as a model of "poor helping poor." As Xi [76] noted in Global Poverty Reduction and Development Forum in 2015

We adhere to the development-oriented approach to poverty alleviation, and regard development as the fundamental way to solve poverty, both to help the poor and to motivate them, and to mobilize the enthusiasm of the people who are helping the poor ... while committed to eliminating poverty on their own, we have always actively carried out South-South cooperation to the best of our ability and to other developing countries. Provide assistance without any political conditions to support and help the majority of developing countries, especially the least developed countries, to eradicate poverty.

In short, the transformation of China's foreign aid lies in the careful use of foreign aid funds. The Chinese government argues that its mutually beneficial model has achieved 
notable successes and is more sustainable. Over the past two decades, China has been active in setting up business deals with African countries [9]. Many of these investments come in a package form, together with aid and loans. Between 1980 and 2000, Sino-African trade increased from $\$ 1$ billion to $\$ 10$ billion [72]. By 2005, this number had reached \$39.7 and in 2006 to \$55 billion, making China Africa's second largest trading partner (after the U.S.) [23]. This number keeps increasing; in 2017, it reached $\$ 170$ billion [39]. During the Forum on China-Africa Cooperation (FOCAC) Summit of December 2015 in Johannesburg, President Xi promised to invest an additional \$60 billion over the next 3 years in loans and aid to the African Continent [13].

Notably, Chinese aid and economic cooperation programs have emphasized infrastructure and production fields, which Western donors have downplayed in recent years $[9,22]$. Over sixty percentage of China's concessional loans are invested in Africa's infrastructure such as transportation, communications, and power [64]. To Beijing, infrastructure would attract more investment, creating more employment opportunities and finally alleviating poverty. As stated by a Chinese Foreign Ministry spokesperson, "Chinese companies have built a lot of highways, railways, ports, airports and communication facilities, greatly improving Africa's economic development environment and helping Africa attract foreign investment" [77]. He further insisted that attention should be paid "to both the economic and social benefits of projects and increasing African countries' ability for independent and sustainable development" [77]. China has achieved success in some infrastructure areas. For instance, according to the International Energy Agency report [27] which examines China's involvement in Africa's electricity supply systems, while sub-Saharan Africa is still facing major electrification challenges, Chinese investment between 2010 and 2015 accounted for $\$ 13$ billion in financing for infrastructure development, benefiting more than 635 million people living without electricity in sub-Saharan Africa. "African countries have relied heavily on China to support the expansion of their electricity systems, to enable growth and improve living standards," said Paul Simons, the IEA's Deputy Executive Director [28].

China has recently been interested in providing investment and aid to support factories that manufacture goods for export too. Chinese companies have increasingly started to outsource their manufacturing to Africa. Through establishing Special Economic Zones (SEZs) in some of Africa's biggest economic hubs such as Egypt, Nigeria, South Africa, and Zambia, China aims to replicate its own development model in which export-oriented industrial hubs were able to appeal to big multinational corporations. These corporations would then invest large sums of money in the local economy, and thereby facilitate continental economic growth. The Chinese government asserts that this resulted in a win-win situation with Chinese wages in the manufacturing sector soaring through the roof, and the rapid increase in Chinese purchasing power which forced Chinese companies to look outside of its national borders in order to maintain their profit margin [3]. In doing so, it created a lot of extra employment in Africa as it aided the continent in establishing a well-functioning manufacturing industry, giving a significant boost to the African economy. Clearly, China's developmental experience informs how Chinese policymakers frame what they perceive as their benevolent aid policy towards African states.

The Chinese government argues that its new approach to Africa has shaped new business opportunities that, in addition to facilitating further economic growth and 
industrial transformation in China, have helped to strengthen the sustainable development of African economies and raised local people out of poverty. To make their case, Chinese policymakers point to joint-ventures such as the one between Chinese oil company Sinopec and the South African firm PetroSA in 2012. They looked into options for constructing a $\$ 10$ billion oil refinery near the port city of Durban [44]. South Africa does not possess an abundance of gas and oil reserves that some of its neighbors have, and is thus almost completely dependent on oil and gas imports [70]. The Chinese/South African refinery has therefore been designed to supply the South African energy sector, and to strengthen South African energy security, and not for resource exports to China.

The aid programs and economic cooperation between developing countries cannot be sustained unless they benefit both partners. As argued by Brautigam, critics should consider Chinese claims that its aid fosters mutual benefit, as China is a developing country with deep poverty in many regions. She argues that it would be "irresponsible to set aside large amounts of funding for the sole benefit of other countries, many with higher income levels" [9]. In this way, China's developmental aid over the years can be regarded as a relationship between donor and recipient as one of "a partnership, not a one way transfer of charity" [9]. Chinese officials maintain that they have been able adjust their African strategy and the way China conducts its business according to local customs, in order to respond to critiques of its policy and to become a genuine collaborative partner for African states. By stimulating the establishment of mutually beneficial partnerships between local and Chinese corporations, China hopes to pursue the national interests of both itself and the African states at once.

In short, China's aid and investment relations with African states are informed by its constructed identity narratives that emphasize China's benevolence and non-interference. Through a rhetoric of "mutual benefit," Chinese leaders extoll the benefits of development, not only for African economies but also in terms of spillover effects that enrich society as a whole and realize human security goals by alleviating poverty. It remains to be seen, however, whether China's Africa policy can truly be said to bolster the security of human beings.

\section{China's "Win-Win" Rhetoric and Human Insecurity}

China's rhetoric of "mutually beneficial" outcomes in its relations with Africa and the benefits accrued to local communities can be challenged, raising the question of whether communities have become more insecure as a result. First, references to Confucian thought and the emphasis on a Chinese developmental model depict the Chinese state as the dominant actor that has the authority to enact and implement human security policies. As a result, Chinese foreign policymakers and businesses have eagerly engaged African elites, ignoring resistance from local communities which have borne the brunt of China's commercial activities [43]. For example, Chinese commercial investments in Zambia's copper mining industry, supported with funds from the Chinese government, led to numerous charges of worker abuse and exploitation and poor safety and health standards [34]. The emphasis in commercial profit over worker safety culminated in a major industrial disaster at the Chinese-owned Beijing General Research Institute of Mining and Metallurgy in Chambishi in April 2005, killing 52 workers [34]. 
In addition, China's collusion with African elites to forcibly appropriate agricultural land in Rwanda, Ethiopia, and Zimbabwe, among others, harks back to Maoist policies to industrialize the countryside at the expense of the rural poor [57]. Another aspect of China's foreign policy that has angered Africa's non-elite has been the tendency to import workers from China rather than to hire locally [1]. In response to China's approach, Chinese workers in Nigeria have been kidnapped and demonstrations have taken place in Angola, for example [57]. Chinese foreign policymakers allow little room for these bottom-up critiques as their foreign policy rhetoric is infused with hierarchical Confucian thinking and an emphasis on the supposedly "unique" qualities of its developmental model.

Second, the "uniqueness" of China's developmental approach can be questioned, as China learned from the Japanese model of development, incorporating key aspects of Japan's aid policy. China's developmental approach has also failed to consider how development itself is rooted in colonial discourse and practice and how it creates a poor, needy other for "our" strong, advanced societies to transform in "our" image, to be like "us," but never become "us." In a way, China's resource politics on the African continent are quite similar to the behavior of imperialist powers; a comparison that critics outside Africa's elite have made [2, 57].

Third, Chinese attempts to differentiate its foreign policy to Africa from former imperialist powers lie in an emphasis on its victim narrative. This victim narrative magnifies the notion of China's glorious economic rise and success at alleviating poverty domestically, without due consideration for the shortcomings of China's own developmental experiences, including inequality, property rights, and pollution. China's victim narrative and confidence in its own developmental successes inhibits any consideration that China's foreign policy may be creating its own victims.

Forth, the emphasis on sovereignty in Chinese interpretations of human security indicates that national interests, or more specifically national survival, are the supreme, if not the only concern of Chinese foreign policymakers. As human security reflects the interests of the state, it encourages its policymakers to arbitrarily exclude (or include) systems of thought to realize the national interest. China's state-centric approach has encouraged numerous critics to charge that China's foreign policy in Africa is concerned with exerting geopolitical or geo-economic influence in exchange for political returns and privileges from African countries. This political influence China is geared to obtaining African countries' support in international relations, such as backing China's approaches to South China Sea dispute or China's "One China Principle" [58], or to back China's stance in international fora, such as mirroring Chinese votes in the UN General Assembly [20]. Alternatively, critics assert that China is engaged in "debt trap diplomacy" in Africa, as a means to gain strategic leverage over African states [8, 73]. Following China's Belt Road Initiative (BRI), the Center for Global Development likewise believes that China's large-scale infrastructure poses a significant debt risk to recipient countries. Key financing countries under the BRI including Djibouti, Egypt, Ethiopia, and Kenya are all likely to face debt crisis [25]. ${ }^{4}$

Fifth, it is important to highlight that China's discourse is inherently contradictory. The concept of Tianxia designates unequal relations between the core, China, and the periphery,

\footnotetext{
${ }^{4}$ Some of these Western critiques might be hypocritical since it was the policies of international financial institutions and Western states that got African states into debt in the first place.
} 
Africa. This contradicts China's win-win discourse based on equal relations between China and African states and "poor helping poor." China's victim narrative and claims to be a developing state also sit uneasily with China's economic rise and articulation of a global vision based on its supposedly "unique" developmental experience. By appropriating this developmentalist discourse from Japan, China's foreign policy rhetoric undermines the notion of "China as a victim" in the sense that Japan is demonized in China's foreign policy discourse, while being a contributor to China's development success.

In sum, the rhetorical basis of China's foreign policy towards Africa derives from its Confucian traditions, victim narrative, and developmental experience. None of this rhetoric enables a critical self-reflection about the downsides of China's developmental model or approach to foreign aid. In terms of human insecurity, land grabs, exploitation of workers, and environmental destruction are among the numerous charges leveled at the Chinese government and businesses operating in Africa. Without a re-evaluation of Chinese rhetoric that allows for voices from the grassroots to be heard, Chinese foreign policy practices are unlikely to change.

\section{Conclusion}

Numerous accounts by academics, think tanks, policymakers, and the media continue to characterize China's Africa policy in terms of neocolonialism. The Chinese government has sought to develop a foreign policy that engages with the notion of human security in order to challenge these critics. For the Chinese government, human security is primarily focused on development and modernization. These are processes which Chinese officials comprehend in terms of their own country's history and constructed self-identity. In Africa, China's noninterference and "win-win" approach forms the basis of the Chinese government's rhetoric to distinguish the Chinese approach from the invasive and paternalistic West. In some ways, both the Western critics and the Chinese proponents of China's Africa policy rely on similar discourses of neocolonialism to make their point.

Most critiques of China's foreign policy towards Africa have focused on exposing the impacts and practices of Chinese aid, they have not considered the rhetoric on which Sino-African relations are based. This lack of consideration for China's rhetoric is due to a specific understanding of human security that emphasizes interventions, neoliberal economic theory and practice, democratization, good governance, and human rights. Taking China's foreign policy rhetoric seriously enables a reconsideration of how Chinese foreign policymakers are able to sustain their relations with African elites in the public domain. At the same time, a critical review of this rhetoric exposes how the discursive foundations on which it is based inhibit self-reflection and a reconsideration of how China's actions in Africa may be undermining human security.

While China's Africa policy has certainly created employment, enhanced trade, and built crucial infrastructure, the benefits have predominantly accrued to Africa's elite in many cases. The focus of China's policy towards Africa with its win-win rhetoric is about securing business interests and thereby advances an exploitative neoliberal agenda. With time, perhaps wages on the African continent will rise, but only as cultures are replaced with neoliberal ideology, land is appropriated, workers exploited, and the environment despoiled. A critical approach to human security should involve communities being at the center of the decision-making process; determining what are threats to their community and how these 
threats should be tackled. In contrast, China's Africa policy clearly raises numerous concerns about how human beings are made insecure through land grabs, environmental degradation, or exploitation in the workplace. Even when Chinese foreign policymakers and corporate elites have adjusted their policies in response to African protests about the impacts of China's foreign and commercial practices, these adjustments have been both reactive and incremental. If China cannot find a more effective way to tackle human security concerns in Africa, then Chinese people and firms will continue to face protests on the continent, including violent resistance [47], as well as to encourage the view that China's approach is anything but "win-win."

\section{Compliance with Ethical Standards}

This article does not contain any studies involving animals and human participants performed by any of the authors.

Conflict of Interest The authors declare that they have no conflicts of interest.

Open Access This article is licensed under a Creative Commons Attribution 4.0 International License, which permits use, sharing, adaptation, distribution and reproduction in any medium or format, as long as you give appropriate credit to the original author(s) and the source, provide a link to the Creative Commons licence, and indicate if changes were made. The images or other third party material in this article are included in the article's Creative Commons licence, unless indicated otherwise in a credit line to the material. If material is not included in the article's Creative Commons licence and your intended use is not permitted by statutory regulation or exceeds the permitted use, you will need to obtain permission directly from the copyright holder. To view a copy of this licence, visit http://creativecommons.org/licenses/by/4.0/.

\section{References}

1. Alden, C. \& Davies, M. (2006). A Profile of the Operations of Chinese Multinationals in Africa. South African Journal of International Affairs, 13(1), 83-96.

2. Alden, C. \& Large, D. (2011). China's Exceptionalism and the Challenges of Delivering Difference in Africa. Journal of Contemporary China. https://www.tandfonline.com/doi/abs/10.1080 /10670564.2011.520844. Accessed 12 January 2016.

3. Alves, A.C. (2013). China's "Win-win" Cooperation: Unpacking the Impact of Infrastructure-forresources Deals in Africa. South African Journal of International Affairs 20(2), 207-226.

4. Bader, J. (2015). Propping up Dictators? Economic Cooperation from China and Its Impact on Authoritarian Persistence in Party and Non-party Regimes. European Journal of Political Research 54(4), 655-672.

5. BBC News (2015). Zuma Says China-Africa Co-Operation 'Win-Win. http://www.bbc.com/news/worldafrica-35018241. Accessed 12 January 2016.

6. BBC News (2017). Theresa May: UK and US Cannot Return to "Failed" Interventions. http://www.bbc. com/news/uk-politics-38747979. Accessed 14 February 2017.

7. Berg, E. (1981). Accelerated Development in Sub-Saharan Africa: An Agenda for Action. Washington, D.C.: The World Bank.

8. Bolton, J.R. (2018). Remarks by National Security Advisor Ambassador John R. Bolton on the Trump Administration's New Africa Strategy. The White House, 13 December 2018. https:/www.whitehouse. gov/briefings-statements/remarks-national-security-advisor-ambassador-john-r-bolton-trumpadministrations-new-africa-strategy/. Accessed 8 January 2020.

9. Brautigam, D. (2009). The Dragon's Gift: The Real Story of China in Africa. Oxford: Oxford University Press.

10. Brautigam, D. (2011). Chinese Development Aid in Africa: What, Where, Why, and How Much?. In J. Golley and L. Song (Eds), Rising China: Global Challenges and Opportunities. Canberra, ANU Press. 
11. Brautigam, D. (2015). Five Myths about Chinese Investment in Africa. Foreign Policy, http://foreignpolicy.com/2015/12/04/5-myths-about-chinese-investment-in-africa/. Accessed 12 January 2016.

12. Breslin, S. (2015). Debating Human Security in China: Towards Discursive Power?. Journal of Contemporary Asia, 45(2), 243-265.

13. Brock, J. \& Mapenzauswa, S. (2015). China’s Xi Cheers African Leaders With Pledge of $\$ 60$ Billion for Development. Reuters. http://www.reuters.com/article/us-china-africa-idUSKBN0TN0MD20151204. Accessed 14 August 2018.

14. Callahan, W.A. (2008). Chinese Visions of World Order: Post-Hegemonic or a New Hegemony? International Studies Review, 10(4), 749-761.

15. Chandler, D. \& Hynek, N. (Eds.) (2011). Critical Perspectives on Human Security. London: Routledge.

16. China.org.cn (2015). A Holistic View of National Security. http://www.china.org.cn/english/china_key_ words/2015-09/07/content_36528050.htm. Accessed 12 January 2016.

17. Cunningham-Cross, L. \& Callahan, W.A. (2011). "Ancient Chinese Power, Modern Chinese Thought." Chinese Journal of International Politics, 4(4), 349-374.

18. de Bary, T. (1998). Asian Values and Human Rights: A Confucian Communitarian Perspective. Cambridge: Harvard University Press.

19. Do, T. (2015). China's Rise and the "Chinese Dream" in International Relations Theory. Global Change, Peace and Security, 21(1), 21-38.

20. Dreher, A., Fuchs A, Parks B., Strange A.M., Tierney M.J. (2017). Aid, China, and Growth: Evidence from a New Global Development Finance Dataset. AidData Working Paper 46. Williamsburg: VA AidData.

21. Dreher, A., Fuchs, A, Parks, B., Strange, A.M. \& Tierney, M.J. (2018). Apples and Dragon Fruits: The Determinants of Aid and Other Forms of State Financing from China to Africa. International Studies Quarterly, 62(1), 182-194.

22. Gonzalez-Vicente, R. (2011). China's Engagement in South America and Africa's Extractive Sectors: New Perspectives for Resource Curse Theories. The Pacific Review 24(1), p.71.

23. Harman, D. (2007). China Boosts African Economies, Offering A "Second Opportunity." The Christian Science Monitor. https:/www.csmonitor.com/2007/0625/p12s01-woaf.html. Accessed 14 August 2018.

24. Human Rights Magazine (2009). Wang Chen: China Registers Historic Progress in Human Rights. Human Rights Magazine 8(1), 3-10.

25. Hurley, J., Morris S., and Portelance G. (2018) Examining the Debt Implications of the Belt and Road Initiative from a Policy Perspective. CGD Policy Paper, No. 121. Washington DC: Center for Global Development.

26. Hwang, Y. 2010. "Olympiad, A Place of Linguistic Struggle: The Discursive Constitution of "Human Rights' in the 2008 Beijing Olympics." Sport in Society 13(5), 855-875.

27. IEA (2016a). Partner Country Series - Boosting the Power Sector in Sub-Saharan Africa: China's Involvement. https://webstore.iea.org/partner-country-series-boosting-the-power-sector-in-sub-saharanafrica. Accessed 20 August 2018.

28. IEA (2016b). New IEA Report Maps Chinese Investments in Africa's Power Sector. https://www.iea. $\mathrm{org} /$ newsroom/news/2016/july/new-iea-report-maps-chinese-investments-in-africas-power-sector.html. Accessed 20 August 2018.

29. Kabia, J.M. (2009). Humanitarian Intervention and Conflict Resolution in West Africa: From ECOMOG to ECOMIL. Burlington: Ashgate.

30. Kang, D. (2010). Hierarchy and Legitimacy in International Systems: The Tribute System in Early Modern East Asia. Security Studies 19(4), 591-622.

31. Kilama, E.G. (2016). The Influence of China and Emerging Donors Aid Allocation: A Recipient Perspective. Chins Economic Review, 38, 76-91.

32. Krause, K. (2004). The Key to a Powerful Agenda, if Properly Delimited. Security Dialogue 35(3), 267268.

33. Kristensen, P. \& Nielsen, R. (2013). Constructing A Chinese International Relations Theory: A Sociological Approach to Intellectual Innovation. International Political Sociology 7, 19-40.

34. Lee, C.K, (2009). Raw Encounters: Chinese Managers, African Workers and the Politics of Casualization in Africa's Chinese Enclaves. The China Quarterly, 199, 647-666.

35. Li, S. (2005). From Relief-type to Development-oriented: Transformation of Poverty Reduction Thoughts (從救濟式到開發式:中國扶貧思想的轉變). Journal of China Three Gorges University, 27, p. 107.

36. Liu, P.H. (2016). One Stereotype, Two Diverse Policies: Comparing Taiwan and China's "Gods of Agriculture" in Africa. Mainland China Studies, 59(2): 1-35. 
37. Manners, I. (2002). Normative Power Europe: A Contradiction in Terms?, Journal of Common Market Studies 40(2), 235-258.

38. Mawdsley, E. (2008). Fu Manchu versus Dr Livingstone in the Dark Continent: Representing, China, Africa and the West in British Broadsheet Newspapers. Political Geography 27, 509-29.

39. Ministry of Commerce, PRC (2018). Statistics on China-Africa Bilateral Trade in 2017. http://english. mofcom.gov.cn/article/statistic/lanmubb/AsiaAfrica/201803/20180302719613.shtml. Accessed 17 August 2018.

40. MOFA, PRC (2000). Premier Zhou Enlai's Three Tours of Asian and African Countries. http://www. fmprc.gov.cn/eng/ziliao/3602/3604/t18001.htm. Accessed 12 January 2016.

41. MOFA, PRC (2002). China's Position Paper on the New Security Concept. In https://www.fmprc.gov.cn/ web/ziliao_674904/tytj_674911/zcwj_674915/t4549.shtml. Accessed 6 January 2020.

42. MOFA, PRC (2004). Hu Jintao Attends the APEC Leadership Working Luncheon and the DeclarationReading Ceremony. http://www.fmprc.gov.cn/mfa_eng/topics_665678/huvisit_665888/t171657.shtml. Accessed 12 January 2016.

43. Mohan, G. \& Lampert, B. (2013). Negotiating China: Reinserting African Agency into China-Africa Relations. African Affairs 112(446), 92-110.

44. Mungadze, S.P. (2013). Sinopec Sign Deal for $\$ 10 B n$ Refinery at Coega', Business Day Live. http://www.bdlive.co.za/business/industrials/2013/03/26/petrosa-sinopec-sign-deal-for-10bn-refinery-atcoega. Accessed 12 January 2016.

45. Naim, M. (2007). Rogue Aid. Foreign Policy, 159, 95-96.

46. Newman, E. (2010). Critical Human Security Studies. Review of International Studies 36, 77-94.

47. Obi, C. (2008). Enter the Dragon? Chinese Oil Companies and Resistance in the Niger Delta. Review of African Political Economy 35(117), 417-434.

48. OECD. DAC Glossary of Key Terms and Concepts. https://www.oecd.org/dac/stats/dac-glossary.htm. Accessed 8 January 2020.

49. Pan, S. \& Lo, J.T. (2017). Re-conceptualizing China's Rise as A Global Power: A Neo-tributary Perspective. The Pacific Review, 30(1), 1-25.

50. Pang, Z. (2005). China's Changing Attitude to UN Peacekeeping. International Peacekeeping 12(1), p. 99.

51. Pasha, M.K. (2013). Introduction. In M.K. Pasha (Ed.). Globalization, Difference, and Human Security. Abingdon and New York: Routledge.

52. People's Daily (2006). China's Premier Wen Gives Press Conference in Cairo. http://english.peopledaily. com.cn/200606/19/eng20060619_275294.html. Accessed 21 August 2018.

53. People's Daily (2008). “Orientation and Path of Reform \& Opening Up Entirely Correct. People's Daily Online. http://english.peopledaily.com.cn/90001/90780/91342/6545553.html. Accessed 17 August 2018.

54. Qi, G. (1995). Further Reforming Foreign Aid under New Situation (在新形勢下進一步改革援外工作). Journal of International Economic Cooperation (國際經濟合作), 11, 4-5.

55. Qin, Y. (2018). A Relational Theory of World Politics. Cambridge: Cambridge University Press.

56. Rafferty, K. (2010). Pernicious "Rogue" Offers of Aid. Japan Times. https://www.japantimes.co. jp/opinion/2010/12/19/commentary/world-commentary/pernicious-rogue-offers-of-aid/\#.W3ME1n59g0 o. Accessed 14 August 2018.

57. Rich, T.S. \& S. Recker (2013). Understanding Sino-African Relations: Neocolonialism or a New Era?. Journal of International and Area Studies, 20(1), 61-76.

58. Sautman, B. \& Yan, H. (2007). Friends and Interests: China's Distinctive Links with Africa. African Studies Review, 50(3), 75-114.

59. Sautman, B. \& Yan, H. (2009). African Perspectives on China-Africa Links. The China Quarterly, 199, $728-759$.

60. Shani, G. (2014). Religion, Identity and Human Security. Abingdon and New York: Routledge.

61. Shani, G., Sato, M. \& Pasha M. (Eds). 2007. Protecting Human Security in a Post 9/11 World: Critical and Global Insights. Basingstoke: Palgrave Macmillan.

62. Söderberg, M. (2011). Japan's ODA as Soft Power. In P. Jain, and B. Stephens (Eds), Japan in Decline: Fact or Fiction?. Folkestone: Global Oriental.

63. Sparks, D. (2011). India and China's Growing Economic Involvement in Sub-Saharan Africa, Journal of African Studies and Development, 3(4), 65-75.

64. State Council, PRC (2011). White Paper on China's Foreign Aid. http://english.www.gov. cn/archive/white_paper/2014/09/09/content_281474986284620.htm. Accessed 8 January 2020.

65. State Council, PRC (2015). Made in China 2025. http://www.cittadellascienza.it/cina/wpcontent/uploads/2017/02/IoT-ONE-Made-in-China-2025.pdf. Accessed 17 August 2018.

66. Taylor, I. (2006). China's Oil Diplomacy in Africa. International Affairs, 82(5), p. 958. 
67. The Economist (2018). China's Plan to Eliminate Poverty by 2020. http://country.eiu.com/article. aspx?articleid=536285437\&Country=China\&topic=Economy. Accessed 17 August 2018.

68. Tiffen, A. (2014). The New Neo-Colonialism in Africa. Global Policy. http://www.globalpolicyjournal. com/blog/19/08/2014/new-neo-colonialism-africa. Accessed 23 February 2017.

69. Tsao, H., Lu, C. \& Yeh, R. (2015). China's Outward FDI in Africa: Enterprises with Different Ownership Types. Contemporary Chinese Political Economy and Strategic Relations: An International Journal, 1(2), 489-527.

70. U.S. Energy Information Administration (2015). Country Report: South Africa, http://www.eia. gov/beta/international/analysis includes/countries long/South Africa/south africa.pdf. Accessed 12 January 2016.

71. UNDP (1993). Human Development Report 1993. New York: Oxford University Press.

72. Wonacott, P. (2011). In Africa, U.S. Watches China's Rise. The Wall Street Journal. http://www.wsj. com/articles/SB10001424053111903392904576510271838147248. Accessed 17 August 2018.

73. World Bank (2006). IDA countries and non-concessional debt: dealing with the free-rider problem in IDA 14 grant-recipient and post-MDRI countries. http://documents.worldbank. org/curated/en/459861468138861852/IDA-countries-and-non-concessional-debt-dealing-with-the-freerider-problem-in-IDA-14-grant-recipient-and-post-MDRI-countries. Accessed 8 January 2020.

74. Wu, G. (2013). China's Challenges to Human Security: Foreign Relations and Global Implications. London: Routledge.

75. Xi, J. (2014). New Asian Security Concept for New Progress in Security Cooperation. Remarks at the Fourth Summit of the Conference on Interaction and Confidence Building Measures in Asia. http://www. chinausfocus.com/wp-content/uploads/2014/07/Xi-01.pdf. Accessed 14 August 2018.

76. Xi, J. (2015). Xi Addresses 2015 Global Poverty Reduction and Development Forum. http://cpc.people. com.cn/BIG5/n/2015/1016/c64094-27707818.html. Accessed 8 January 2020.

77. Xinhua (2018). China Calls for Fair, Objective View of China-Africa Cooperation. http://www.xinhuanet. com/english/2018-03/06/c_137020346.htm. Accessed 14 August 2018.

78. Yan, X. (2011) Ancient Chinese Thought, Modern Chinese Power. Translated by Edmund Ryden. Edited by Daniel A. Bell and Sun Zhe. Princeton: Princeton University Press.

79. Yang, H. (2009). Chinese Foreign Aid and Investment (中國對外援助與發展), Study Monthly, 439, 40-42.

80. Yu, C. and Chang, T. (2011). China's African Policy: An Analysis of Soft Power and the Tributary System. Prospect Quarterly 12(4), 111-156.

81. Zhao, T. (2015). Redefining the Concept of the Political with Tianxia: Its Questions, Conditions and Methodology (以天下重新定义政治概念、问题、条件和方法). World Politics and Economics, 6, 4-22.

82. Zheng, Y. (2013). The Rediscovery of the Tianxia World Order. In G. Rozman (Ed.) National Identities and Bilateral Relations: Widening Gaps in East Asia and Chinese Demonization of The United States (pp. 127-152). US: Stanford University Press.

83. Zweig, D., \& Bi, J. (2005). China's Global Hunt for Energy. Foreign Affairs, 84, p. 32.

Publisher's Note Springer Nature remains neutral with regard to jurisdictional claims in published maps and institutional affiliations. 